\title{
LEGAL APPLICATION OF THE RIGHT TO DATA PORTABILITY IN PEER TO PEER (P2P) LENDING IN INDONESIA
}

\author{
Ori Setianto, Hendrawan Agusta, Annisa Putri Nadya, Rudy Siahaan, Gika Asdina Firanda \\ OSS Partnership, Pemerhati Fintech. \\ Korespondensi email: hagusta@yahoo.com
}

\begin{abstract}
Once Personal Data entered into an Electronic System has become Electronic Information in digital form. It can be seen using parameters that the Personal Data is no longer in atom base format but has changed to byte base format. Electronic Information in IT Law approach can be transmitted between Electronic Systems in a possible connection. Data Portability arise, one of which is to allow Data Subject as the Application User to transmit his Personal Data from one Electronic System to another for his own benefit, with the consent and or request of the Data Subject. The development of Data Portability is influenced by the European Union through the General Data Protection Regulation (GDPR), where this is one of the factors that must be considered along with the development of Data is The New Oil phenomenon. P2P Lending business model as a part of Financial Technology (Fintech) in the registration process for Lending accounts is also related to Data Portability. This journal discusses on how the application of The Right to Data Portability in P2P Lending in Indonesia.
\end{abstract}

Keywords : Legal; Personal Data; The Right to Data Portability; Fintech; P2P Lending

\section{INTRODUCTION}

\section{Background}

Fintech is one of the innovations in the field of financial services as a result of the symbiosis between the field of highly regulated finance and the field of information technology. ${ }^{1}$ By the Fintech Bali Agenda set out on October 11, 2018, several corridors must be considered, namely2: (1) a qualified data infrastructure, (2) inclusive finance and financial market development, (3) adapting the regulatory framework of supervision for the development of a stable financial system, (4) closely monitor developments to improve understanding of the evolving financial system, (5) coordination and international cooperation, (6) maintain financial integrity, (7) ensure monetary system stability, (8) develop collective supervision, (9) use new technologies to improve financial services, (10) provide an accommodating legal landscape, (11) encourage competition and

2 Widyo Gunadi. (Submitted to November 28, 2018). "Conference matery: Regulasi Fintech Pada Era Industri 4.0". Conference of Digital Transformation and Industry 4.0 in Jakarta
Implementasi Asas Itikad Baik Dalam Perjanjian

Transaksi Jual Beli Online. JURNAL LEGALITAS, 12(2), 90-99. 
commit to creating open markets, and (12) welcome revolution in the financial industry.

The consequences of fintech development required clarity in terms of legal certainty, security in terms of information technology, and consumer protection. ${ }^{3}$ These three things must be controlled by the Regulator, both 0JK in terms of registration and licensing (business process), Information from the electronic system (engineering process). ${ }^{4}$ Based on positive legal provisions in Indonesia, there are 5 (five) categories of Fintech, consisting of ${ }^{5}$ :

1. Payment System, including authorization, clearing, final settlement, and payment implementation, for example, the use of blockchain technology or distributed ledger for the implementation of fund transfer, electronic money, electronic wallets, and mobile payments.

2. Market Support, is a Fintech that uses information technology and/or electronic technology to facilitate the provision of faster and cheaper information related to financial products and/or services to the public, for example, the provision of comparative data on financial products or services.

3. Investment Management and Risk Management, for example, the provision of online investment products and online insurance.

4. Loans, Financing, and Capital Provision, for example, information technology-based lending services (peer-to-peer lending) as well as financing or

3 Amer, N. (2020). Analisis Pembubaran Organisasi Kemasyarakatan Dalam Perspektif Negara Hukum. JURNAL LEGALITAS, 13(01), 1-15.

4 Alhasni, M. R., Badu, L. W., \& Nggilu, N. M. (2019). Menakar Peran Kepolisian Dalam Mencegah Tindak Pidana Pencabulan Terhadap Anak di Bawah Umur. JURNAL LEGALITAS, 12(2), 110-123

5 Article 1 Number (3) regulation of the Financial Services Authority No. 77 of 2016 concerning Information Technology-Based Money Borrowing Services. fundraising based on information technology (crowd-funding).

5. Other Financial Services."

Peer to Peer Lending or P2P Lending is the implementation of financial services to bring lenders together with loan recipients to make loan agreements in Rupiah currency directly through electronic systems using the internet network. ${ }^{6}$ The presence of P2P Lending can not be separated from the need for people to obtain money loans, which can be obtained through banks, but the demand is a lot and the disbursement of loans is quite time-consuming. Although it is only in the early stages, Fintech has the effect of destroying the "bank house" that we know, perhaps someone has heard Bill Gates say, "Banking is necessary, banks are not"? Yes, now banks are no longer the only major source of financing. ${ }^{7}$ The legal basis ${ }^{8}$ for the implementation of P2P Lending is contained in the Regulation of the Financial Services Authority No. 77/POJK.01/2016 on Information Technology-Based Money Lending Services (POJK No. 77). The alternative offered by POJK No. 77 is a fresh wind for people who need loans practically unlike applying for credit through banks whose procedures are long, time-consuming, and collateral.

Discussion about The Right to Data Portability (RtDP) must be about data in digital form that can be transposed between Electronic Systems. In P2P Lending there are three types of data, namely Personal Data, Transaction Data, and Financial Data. ${ }^{9}$ The

6 Lakoro, A., Badu, L., \& Achir, N. (2020). Lemahnya Kepolisian Dalam Penanganan Tindak Pidana Perjudian Togel Online. JURNAL LEGALITAS, 13(01), 31-50.

7 Rhenald Kasali. (2017). “Disruption”, cet. 6. Jakarta: PT Gramedia Pustaka Utama. pg. 97

8 Ahmad, D., \& Thalib, M. C. (2019). Tanggung Jawab Hukum Pelaku Usaha Terhadap Peredaran Kosmetik Yang Tidak Memiliki Izin Edar. JURNAL LEGALITAS, 12(2), 100-109

9 Article 26 letter (a) Regulation of the Financial Services Authority No. 77 of 2016 concerning 
core parties in the implementation of $\mathrm{P} 2 \mathrm{P}$ Lending there are 3 (three), namely The Organize $^{10}$, Debitur ${ }^{11}$ and Creditur ${ }^{12}$. In this Journal, the author provides a limit that the material discussed is about RtDP in connection with the Personal Data of the LoanEe, for furthermore to facilitate the writing, the author chooses the word Data Subject in reflecting the Owner of Personal Data. Personal Data is certain individual data (any true and tangible information that is inherent and identifiable, directly or indirectly, in each individual) that is stored, maintained, and maintained the truth and protected confidentiality. ${ }^{13}$

In the announcement of the 2020 population census at the State Palace, President Joko widodo explained in his speech that Data became a new type of wealth and more valuable than oil (Data is The New Oil). President Joko Widodo said that valid data can be one of the keys to Indonesia's development. Dennis D. Hirsch said that Data is an important resource that drives the information economy as oil has fueled the industrial economy. ${ }^{14}$ In line with Hirsch's opinion, The Economist noted that "a century ago, the resource in question was oil. Now similar concerns are being raised by the giants that deal in data, the oil of the digital era".15 The more data that is processed and processed, the more things that can be concluded from the data analysis process, in turn, obtained an output, for

Information Technology-Based Money Borrowing Services.

10 An Indonesian legal entity that provides, manages and operates Information Technology-Based Money Lending Services.

11 People, legal entities and/or business entities that have receivables due to information technologybased Money Borrowing Service agreements.

12 People and/or legal entities that have debts due to information technology-based money lending services agreements.

13 Article 1 number (1) regulation of the Minister of Communication and Informatics Number 20 of 2016 concerning the Protection of Personal Data in Electronic Systems. example, a pattern of public purchasing behavior, public appetite for certain products and/or services, and so on. The data is collected into a large data set (Big Data) that promises a large number of new uses for the identification, the emergence of new businesses and business sectors. Big Data provides vital input for the economy and provides the foundation of a new business model. Virginia Rometty, one of the executives of IBM, a U.S. company that manufactures and sells computer hardware and software, said that Big Data is The New Oil ${ }^{16}$, therefore the author concluded that both Data and Big Data are the phenomenon of The New Oil as a game-changer for world electronic transactions, including Indonesia.

Oil is a raw resource, it can only be useful if it has been processed into certain products, such as lubricants and gasoline. This analogy is appropriate to analyze that Data is also a raw resource, it can only be useful after processing and analyzing in such a way through Artificial Intelligence (artificial intelligence) for a specific purpose. Data are analogous to raw material resources, which only acquire direct value in use after they are extracted and processed in specific ways. ${ }^{17}$ More and more businesses are aware of the importance of Big Data as a source of strategy, whereby analyzing consumer purchasing history, a business can easily identify trends and patterns of consumer needs. ${ }^{18}$

14 Dennis D. Hirsch. (ed. June, 2014). “The Glass House Effect: Big Data, The New Oil, and the Power of Analogy”. Maine Law Review Vol. 66 No. 2: 374.

15 David Parkins. "The World's Most Valuable Resource Is No Longer Oil, But Data", Retrieved from https://www.economist.com/leaders/. Accessed November 12, 2020.

16 Ibid.

17 Michele Loi dan Paul Olivier Dehaye. (2017). "If Data Is The New Oil, When Is The Extraction of Value From Data Unjust". Philosophy and Public Issues Tyranny, Democracy, and Economy Vol. 7 No. 2: 139

18 Noriko Higashizawa dan Yuri Aihara. (2017). “Data Privacy Protection of Personal Information Versus Usage of Big Data: Introduction of the Recent Amendment to the Act on the Protection of Personal 
The utilization of P2P Lending presents challenges related to the protection of Personal Data, one of which concerns the processing of such Data. ${ }^{19}$ Personal Data of Application Users entered in $\mathrm{p} 2 \mathrm{p}$ lending application stored in the form of electronic information and/or electronic documents is Digital Property that can be controlled by the property of the Application User as the Data Subject. In other words, Data Subject has a Right to Matter over his/her Personal Data stored by P2P Lending Operators, one of which is RtDP, namely the right to request Personal Data in a format that can be read by electronic systems and request that the Personal Data be transmitted to the Electronic System for the benefit of the Data Subject.

Prospective Users of the P2P Lending Application in addition to registering directly on the P2P Lending application (entering their email address and/or phone number), can also register using a Google account that they have created before. When they use a Google account when registering there is a transfer of Personal Data desired by the Data Subject to the Electronic System of $p 2 p$ lending operators. The process of transfer of Personal Data is called Data Portability, while the right to request the process is called RtDP. The application of RtDP is closely related to interoperability, namely the ability of Data to be shared between electronic systems that interact with each other. ${ }^{20}$ In this Journal, the authors provide a limitation, that the RtDP discussed in P2P Lending is the one that uses Google account registration with the Android operating system (OS), while apple's

Information (Japan)". Defense Counsil Journal Vol. 84 No. 4: 1.

19 Sinta Dewi Rosadi. (2018). "Perlindungan Privasi Dan Data Pribadi Dalam Era Ekonomi Digital Di Indonesia". Jurnal Veritas et Justicia Vol. 4 No. 1: 88

20 Article 1 number (8) of Presidential Regulation No. 39 of 2019 concerning One Indonesian Data

21 Soerjono Soekanto, Sri Mamudji. (2004). "Penelitian Hukum Normatif, cet ke-8". Jakarta: PT Raja Grafindo Persada. Pg. 4.

22 Ahmad, A., \& Nggilu, N. M. (2020). Denyut Nadi Amandemen Kelima UUD 1945 melalui Pelibatan operating system is not discussed in this Journal.

\section{Problem Statement}

Prospective Users of the P2P Lending Application in addition to registering directly on the P2P Lending application (entering their email address and/or phone number), can also register using a Google account that they have created before. When they use a Google account when registering there is a transfer of Personal Data desired by the Data Subject to the Electronic System of $p 2 p$ lending operators. Based on these, it is necessary to review the problem of applying The Right to Data Portability in P2P Lending application (registered) in Indonesia.

\section{Method}

The research method used in this research is normative legal research or doctrinal law research, i.e. ${ }^{21}$ literature research or document studies because this research is conducted or aimed only at written regulations or other legal materials. Doctrinal research consists of research in the form of positive legal inventory efforts, the discovery of principles and philosophies (dogma or doctrine $)^{22}$ of positive law, and the discovery of laws in concreto that are feasible to be applied to resolve a particular legal case. ${ }^{23}$

In this study, the theory that will be used as an analytical knife is the Theory of The Right of The Land. Article 499 of the Civil Code defines the object, namely each item and every right that can be controlled by the property. ${ }^{24}$ The Right of Matter (zakelijk recht) is a right

Mahkamah Konstitusi sebagai Prinsip the Guardian of the Constitution. Jurnal Konstitusi, 16(4), 785808.

23 Saefullah Wiradipradja. (2016). "Penuntun Praktis Metode Penelitian dan Penelitian Karya Ilmiah, cet. 2". Bandung: CV Keni Media. Pg. 28.

24 Fitriani, N. (2019). Tinjauan Yuridis Kekuatan Pembuktian Keterangan Saksi Anak Dalam Persidangan Perkara Pidana. JURNAL LEGALITAS, 12(1), 14-24. 
that gives direct control over an object, in which power can be maintained against each person. ${ }^{25}$ The material right includes tangible and intangibles. One of the characteristics of the Right to Object is absolute, where in the event of interference by a third person, the owner of the property rights can exercise his rights to anyone as well. ${ }^{26}$

\section{DISCUSSION}

\section{The General Data Protection Regulation (GDPR) Effects on the Adequacy of the} Rules Regarding the Right Data Portability in Indonesia.

The Right to Data Portability (RtDP) becomes a means for Data Subject to facilitate the transfer of Personal Data from one Electronic System to another so that it does not take long for the Subject Data to fill in the data needed during the signup process on an application. RtDP also makes it easy for Subject Data to share Personal Data to various Electronic Systems (including but not limited to websites and telematics applications). Before the author elaborates on the effect of GDPR on RtDP in Indonesia, it must first be withdrawn from its genus in a broader perspective from the point of view of Personal Data Protection, because rtdp is in principle included in the Protection of Personal Data.

Personal Data Protection as a Digital Matter is closely related to the aspect of privacy. Edmon Makarim said that in the aspect of privacy there are two models of approach, namely subjective approach, and objective approach ${ }^{27}$. The subjective approach sees not to the matter, but to the value of one's personal rights as a data subject, this approach is embraced by America. The development of Personal Data Protection is based on the decisions of various cases in America that have specific characteristics and

25 Subekti. (1979). "Pokok-Pokok Hukum Perdata". Jakarta: Intermasa. Pg. 52.

26 Wirjono Prodjodikoro. (1993). "Azas-azas Hukum Perjanjian”. Bandung: Sumur Press. Pg. 13-14. certain, there is no single rule on the Protection of Personal Data. America focuses on its subject matter, which is the party that has an interest in privacy. The European Union adheres to the objective approach that looks at its institutions, namely Data. The European Union has the Council of Europe's Convention on Data Protection (EU) and the European Union (EU) Directive, so its legal provisions have broad and comprehensive characteristics (omnibus legislation). It can be said that the Approach to Personal Data Protection by America is less conservative than the European Union because in America it upholds freedom as the main focus and as a goal.

Tabel 1. Comparison of Personal Data Protection Approaches between the European Union and the United States

\begin{tabular}{|c|c|c|}
\hline No. & Uni Eropa & United States \\
\hline 1. & $\begin{array}{l}\text { Lawfullnes, fairly } \\
\text { and transparency }\end{array}$ & $\begin{array}{c}\text { Notice/ } \\
\text { Awareness }\end{array}$ \\
\hline 2. & Purpose Limitation & $\begin{array}{l}\text { Choice/ } \\
\text { Consent }\end{array}$ \\
\hline 3. & Data minimazition & $\begin{array}{c}\text { Access/ } \\
\text { Participation }\end{array}$ \\
\hline 4. & Accuracy & $\begin{array}{c}\text { Integrity/ } \\
\text { Security }\end{array}$ \\
\hline 5. & Storage Limitation & $\begin{array}{c}\text { Enforement/ } \\
\text { Redress }\end{array}$ \\
\hline 6. & $\begin{array}{l}\text { Integrity and } \\
\text { Confidentiality }\end{array}$ & \\
\hline 7. & Accountability & \\
\hline 8. & Data Portability & \\
\hline
\end{tabular}

Source: Teaching Materials the Urgency of Personal Data Protection: Are Indonesia Ready for ASEAN Community 2015 by Edmon Makarim.

In the European Union, there are two rights that must be applied in electronic systems, namely Right to Erasure and RtDP, without the existence of both rights, it is not guaranteed the confidentiality, integrity, and

27 Edmon Makarim. Teaching Materials: "Transaksi Elektronik : E-ID dan Personal Data Protection”. pg. 5. 
availability of a person's Personal Data. The GDPR is a regulation in EU law governing the Protection of Personal Data both inside and outside the European Union. The GDPR is a complement to the European Union Directive 95/46/EC on The Protection of Individuals With Regard to The Processing of Personal Data and on The Free Movement of Such Data in the European Union. The GDPR came into force in the European Union on 25 May 2018. Underlining the establishment of the GDPR is the Charter of Human Rights of the European Union, which stipulates that EU citizens have the right to protect their Personal Data. GDPR is one of the most comprehensive regulations (omnibus law) related to Personal Data Protection which is now also the benchmark of Personal Data Protection law in the world.

The subject of the GDPR is a resident of the European Union, so businesses around the world that process and store EU resident data are bound and subject to the GDPR. The Personal Data of EU citizens follows and is attached to each individual, the free movement of personal data within the Union shall be neither restricted nor prohibited for reasons connected with the protection of natural persons with regard to the processing of personal data. For example, if there is a company in Indonesia that has an interest in processing and storing the Personal Data of EU citizens, then the processing and retention of Personal Data remainssubject to the GDPR. In the GDPR are regulated principles relating to the Protection of Personal Data, one of which is rtdp which is a new right that has not previously been regulated in the EU Directive. As a new right, data portability has yet to be

28 Janis Wong \& Tristan Henderson. (October 2018). "How Portable is Portable? Exercising the GDPR's Right to Data Portability", Association for Computing Machinery. Pg. 913.

29 Andra Giurgiu \& Gérard Lommel. (2014). “A New Approach to EU Data Protection : More Control over Personal Data and Increased Responsibility". Critical Quarterly for Legislation and Law Vol. 97 No. $1: 17$. tried and tested. ${ }^{28}$ RtDP aims to provide flexibility for Data Subject to obtain and re-use of personal data of a person in various services based on information technology. There are two sides to data portability, the first involves the right to obtain from the controller a copy of the processed data in an electronic and structured format, commonly used which also allows for further use and the second gives data subjects the right to transmit that data from one automated processing system to another, in which cases he provided the data and the processing is based on consent or a contract. ${ }^{29}$ The complete rtdp formulation is contained in Article 20 GDPR, namely:

"The data subject shall have the right to receive the personal data concerning him or her, which he or she has provided to a controller, in a structured, commonly used and machine-readable format and have the right to transmit those data to another controller without hindrance from the controller to which the personal data have been provided."

Based on these formulations, the GDPR requires that data received by the Data Subject must be in a format that can be read by electronic systems and re-operated metadata. Metadata is information in the form of a standard structure and format to describe Data, explain Data, and facilitate the search, use, and management of Data information. ${ }^{30}$ The application of RtDP must be done without any obstacles from the Data Controller, namely the party that determines the purpose and purpose of the processing of Personal Data collected. ${ }^{31}$ This RTDP in its application is closely related to data interoperability and

30 Article 1 number (7) of Presidential Regulation No. 39 of 2019 concerning One Indonesian Data.

31 Controller means the competent authority which, alone or jointly with others, determines the purposes and means of the processing of personal data, where the purposes and means of such processing are determined by Union or Member State law, the controller of the specific criteria for its nomination may be provided for by Union or Member State law, GDPR, Article 3 paragraph (8). 
portability (data flow). RtDP only relates to Personal Data that is processed automatically through information technology, namely through computers. The RTDP only relates to personal data processed by automated means (i.e. by a computer, not paper records). ${ }^{32}$

The EU Directive and GDPR were then followed up with Article 29 of the Data Protection Working Party (WP 29), stating that data portability can make it possible for businesses and Data Subject as consumers of an application to maximize the benefits of Big Data in a more balanced and transparent way. It can also help minimize unfair or discriminatory practices and reduce the risk of inaccurate use of Data for decision-making purposes that will benefit businesses and the Data Subject. ${ }^{33}$

Following up on the interconnected discussion of RtDP with interoperability, the author said that interoperability is not new and there has been a formulation of it as the author said in the introduction. The results of the regulation on interoperability in Indonesia are contained in Presidential Regulation No. 95 of 2018 concerning Electronic Based Governance System (SPBE's Presidential Regulation), Presidential Regulation No. 39 of 2019 concerning One Indonesian Data (SDI's Presidential Regulation), Government Regulation No. 71 of 2019 concerning The Implementation of Electronic Systems and Transactions (PSTE's Government Regulation). The author presented a comparison about the formulation of Data Interoperability between SPBE's Presidential Regulation, One Data Government Regulation, and PSTE's Government Regulation as follows:

Tabel 2. Interoperability Comparison

32 Lachlan Urquhart, Neelima Sailaja dan Derek McAuley. (2017). "Realising the Right to Data Portability for the Domestic Internet Of Things", England: Springer. Pg. 319.

33 Paul De Hert, Vagelis Papakonstantinou, Gianclaudio Malgieri, Laurent Beslay, Ignacio Sanchez. "The Right To Data Portability In The GDPR: Towards User-

\begin{tabular}{|c|c|c|}
\hline $\begin{array}{c}\text { SPBE'S } \\
\text { Presidentia } \\
\text { l Regulation }\end{array}$ & $\begin{array}{c}\text { SDI's } \\
\text { Presidential } \\
\text { Regulation }\end{array}$ & $\begin{array}{c}\text { PSTE's } \\
\text { Government } \\
\text { Regulation }\end{array}$ \\
\hline $\begin{array}{c}\text { Coordination } \\
\text { and } \\
\text { collaboratio } \\
n \text { between } \\
\text { business } \\
\text { processes } \\
\text { and between } \\
\text { Electronic } \\
\text { Systems in } \\
\text { order to } \\
\text { exchange } \\
\text { data, } \\
\text { information, } \\
\text { or SPBE } \\
\text { Services. }\end{array}$ & $\begin{array}{c}\text { Data } \\
\text { capability to } \\
\text { be shared } \\
\text { between } \\
\text { electronic } \\
\text { systems that } \\
\text { interact with } \\
\text { each other. }\end{array}$ & $\begin{array}{c}\text { The ability of } \\
\text { different } \\
\text { Electronic } \\
\text { Systems to be } \\
\text { able to work } \\
\text { in an } \\
\text { integrated } \\
\text { manner. }\end{array}$ \\
\hline
\end{tabular}

From a general overview of interoperability that is closely related to RTDP, the author enters specifically in the P2P Lending industry. RtDP itself has been implemented by the Organizer as a platform. The existence of RtDP makes it easy for Borrowers (Borrowers) as Data Subject to move and/or transmit existing Personal Data in Data Controller such as Google and Facebook to an Organizer during the signup process so that the terms Google Sign Up and Facebook Sign Up appear. In POJK 77 there is an implementation of RtDP, namely the Operator can cooperate and exchange data with supporting service providers based on information technology in order to improve the quality of Information Technology-Based Money Borrowing Services. ${ }^{34}$

Based on the above article, the Operator is permitted by OJK to exchange Data with support services based on information

Centric Interoperability of Digital Services". Computer Law and Security Review, Vol. 34 No. 2: 195

34 Article 23 of Financial Services Authority Regulation No. 77 of 2016 concerning Information TechnologyBased Money Borrowing Services 
technology but still have to pay attention to the Protection of Personal Data from its users. The Operator shall maintain the confidentiality, integrity, and availability of Personal Data, Transaction Data, and Financial Data managed since the Data is obtained until the data is destroyed. ${ }^{35} \mathrm{P} 2 \mathrm{P}$ Lending is a PSE that has an internetnetworked website and/or application used to provide, manage and/or operate financial transaction services ${ }^{36}$, so it should also refer to PP PSTE. The Operator shall ensure the proper functioning of the Electronic System in accordance with its designation while paying attention to Interoperability and Compatibility with previous Electronic Systems and/or related Electronic Systems.

In the PDP Bill, RtDP has also been discussed using the same principle as GDPR, namely that the Owner of Personal Data (Data Subject) is entitled to obtain his Personal Data in the form of appropriate structure and/or storage format commonly used or can be read by machines or hardware used in interoperability between Electronic Systems. ${ }^{37}$ In addition, The Data Subject has the right to transmit and use Personal Data from one Controller to another as long as the system can communicate securely with each other in accordance with the principles of Personal Data Protection. ${ }^{38}$ RtDP regulation on GDPR and PDP Bill does have similarities, this can be said to be reasonable because GDPR is indeed one of the references of countries in the world to regulate Personal Data Protection, moreover Indonesia tends to follow an objective approach (embraced by the European Union) that focuses on Personal Data. The important thing to note is the security settings of Personal Data when exchanging Data (data cross) during the occurrence of Data portability because if not maintained there can be a leakage of Data

35 Ibid, Article 26

36 Article 2 paragraph (5) letter (b) point (1) of Government Regulation No. 71 of 2019 concerning (leakage) that ultimately harms the Data Subject.

Impementation of The Right to Data Portability in P2P Lending Application (Registered) in Indonesia

The application of RtDP can be exemplified in the creation of accounts in the P2P Lending application. For example, the author has randomly opened and selected two P2P Lending applications and the result is for the "maucash" application using how to create an account through Facebook or Google, while the "Borrow Here" application uses a mobile number.

Figure 1 : Creating an account in the "Ammana"

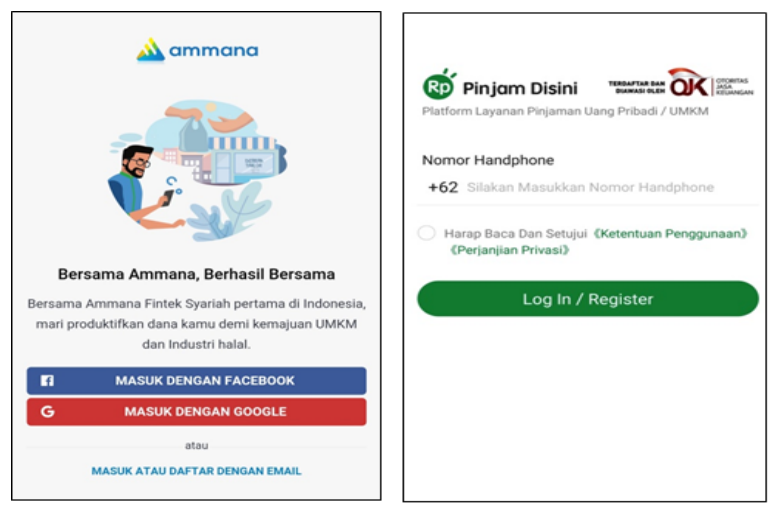

application using Facebook or Google.

Figure 2 : Creating an account in the "Borrow Here" application using a mobile number.

The author tries to use Google Sign Up to register on ammana application, the stage is the author clicks on the "sign in with Google" feature, after it is clicked there is a view to choose an account to continue to Amanna. Instantly an author's Google account appears, or if we have multiple Google accounts, can be selected as desired. In the display there is a Notice (Notice) which contains to continue, Google will share your name, email address, and profile picture with Ammana. From the Notice, the author as Data Subject knows that (a) Personal Data transferred from Google Electronic System to Amanna Electronic System only includes 3 (three) data, namely

The Implementation of Electronic System and Transactions

${ }^{37}$ Article 17 paragraph (1) of the PDP Bill

38 Ibid. Article 17 paragraph (2) 
name, email address, and face photo and (b) between Google Electronic System and Ammana Electronic System there is data interoperability that enables data portability.

After the registration option using a Google account is clicked, a second Notice appears which essentially (a) the portability of data from the Google account to the Amanna Electronic System will allow Ammana to: associate you with your personal info on Google; see your personal info, including any personal info you've made publicly available and view your email address, (b) There is a consent button with the allow feature, that feature if clicked, then it indicates we agree with the Term of Service and Privacy Policies of Ammana, next automatically we have an account in Ammana and we get a confirmation email to the Google account, namely "Your account was successfully activated".

Not all P2P Lending applications use Data transfer using Google Sign Up and/or Facebook Sign Up, most $\mathrm{p} 2 \mathrm{p}$ lending providers still use account creation with mobile number. In addition to maucash applications, out of a total of 158 P2P Lending applications registered and licensed at the $0 \mathrm{JK}^{39}$ from the author's check, there are 7 (seven) P2P Lending applications (including Ammana application) that use RtDP as a means for Application Users to register $p 2 p$ lending application accounts, the data can be submitted as follows:

Tabel 3. List of P2P Lending (Android OS) Applications Registered at OJK Using Data Portability By Registration Through Google Sign Up and/or Facebook Sign Up

\begin{tabular}{lcc}
\hline No. & $\begin{array}{c}\text { Applicatio } \\
\text { n Name }\end{array}$ & Corporation \\
\hline 1. & Ammana & PT Amanna Fintech \\
& & Syariah \\
\hline
\end{tabular}

39 Data of Registered and Licensed P2P Lending Operators at OJK as of August 5, 2020

\begin{tabular}{|c|c|c|}
\hline 2. & Iternak & $\begin{array}{l}\text { PT Perlu Fintech } \\
\text { Indonesia }\end{array}$ \\
\hline 3. & Tani Fund & $\begin{array}{l}\text { PT Tani Fund Madani } \\
\text { Indonesia }\end{array}$ \\
\hline 4. & $\begin{array}{l}\text { Pinjam } \\
\text { Modal }\end{array}$ & $\begin{array}{c}\text { PT Finansial Integrasi } \\
\text { Teknologi }\end{array}$ \\
\hline 5. & Pintek & $\begin{array}{l}\text { PT Pinduit Teknologi } \\
\text { Indonesia }\end{array}$ \\
\hline 6. & $\begin{array}{l}\text { Gandeng } \\
\text { Tangan }\end{array}$ & $\begin{array}{c}\text { PT Kreasi Anak } \\
\text { Indonesia }\end{array}$ \\
\hline 7. & $\begin{array}{l}\text { Modal } \\
\text { Antara }\end{array}$ & $\begin{array}{c}\text { PT Anantara Digital } \\
\text { Indonesi }\end{array}$ \\
\hline
\end{tabular}

This means that if created in a percentage there are about $4.4 \%$ (four point four percent) P2P Lending Organizers who use and/or apply RtDP in the account registration process. These results reflect that not all Of the Organisers' Electronic Systems use interoperability with Google and/or Facebook, which is predictable because even within the GDPR, rtdp is a new, growing right to be implemented using an information technology approach. It is also possible that although the Organizer does not use interoperability with Google and Facebook in the registration of P2P Lending application accounts, the Organizer uses interoperability with third parties to sign digitally (e.g. with Digi Sign).

The results of interviews with the Directorate General of Telematics Applications (Ditjen Aptika) Kominfo related to the application of Data Portability in Fintech, especially P2P Lending obtained information that the application of web-based Data Portability can facilitate data access and data search. Besides, it can improve the accuracy and accuracy of numerical calculations in electronic trading. The existence of information systems in webbased Data Portability in the form of applications can facilitate the administrative process at any time when the public wants. ${ }^{40}$

40 Interview with Muhammad Farhan, staff at the Telecommunications and Application Control 
The issue of Data Portability or Data Portability is an important issue for Fintech, even the Indonesian Fintech Association (AFTECH) in the preparation of the Draft Standards for Personal Data Protection and Data Confidentiality in the Financial Technology Sector (DRAFT PDP AFTECH Standards) make the details of the regulation on Data Portability, namely ${ }^{41}$ :

a) AFTCEH Members may portability of Personal Data and grant rights to the Portability of Personal Data to the Data Subject (Owner of Personal Data) if the AFTECH member has sufficient technical capacity to do so and can guarantee the security of the Process of Portability of such Personal Data;

b) AFTECH Members understand that The Subject Data may receive back the Personal Data that has been provided to its designated Data Controller. Such Personal Data must be acceptable in a structured, commonly used, machinereadable format;

c) AFTECH Members have the right to refuse requests for the fulfillment of data portability from the Personal Data Owner if the request is unfounded, may be risky to the disclosure of other people's Personal Data, or exceed fairness;

d) To reject requests for the fulfillment of unfounded data portability, AFTECH members are obliged to consider each request on a case-by-case basis;

e) If an AFTECH member rejects a request for the fulfillment of data portability from the Data Subject, the AFTECH member clearly communicates the reason for the refusal to the Subject Data.
Each AFTECH member has a clear process flow to ensure the fulfillment of data portability rights from their users that includes at least a method of transferring data from one informatics environment to another and a deadline to respond to requests for the fulfillment of rights to that Data Portability.

\section{CLOSING}

\section{Conclusion}

The effect of GDPR on the adequacy of rtdp rules in Indonesia is related to the principles of Personal Data Protection by directing the Owner of Personal Data (Data Subject) who has the right to obtain his/her Personal Data in an appropriate form structure and/or storage format commonly used or readable by machines or hardware used in interoperability between Electronic Systems. In addition, the implementation of RtDP in the adequacy of rules related to P2P Lending in Indonesia is contained in POJK No. 77, SPBE's Presidential Regulation, SDI's Presidential Regulation, PSTE Government Regulation and PDP AFTECH Draft, in essence: (a) Data Subject can register P2P Lending application using Google Sign-In and Facebook Sign In and (b) The Organizer can cooperate and exchange data with information technology-based support service providers in order to improve the quality of P2P Lending services.

The application of RTDP in P2P Lending application (registered) in Indonesia can be exemplified in the creation of accounts in $p 2 p$ lending applications that can be done through Facebook or Google, so that Personal Data contained in Facebook or Google including names, email addresses and face photos is possible to interoperability of data from Google Electronic System or Facebook to an electronic system of P2P Lending Operators.

Lembaga Kementerian Negara Suatu Praksis Menuju Kabinet Yang Efektif. Al-Ahkam, 15(2), 6980.

41 Article 65 of the AFTECH PDP Standard Draft
Section at the Directorate General of Applications and Informatics (Directorate General of Aptika) of the Ministry of Communication and Informatics, on Wednesday, November 25, 2020. And see in Wijaya, A. (2019). Mekanisme Koordinasi dan Singkronisasi 
Based on the results of checking the authors of a total of 158 P2P Lending applications registered and licensed at the $0 \mathrm{JK}$, there are 7 (seven) P2P Lending applications that use RtDP as a suggestion for Users to register a P2P Lending Application account.

\section{Reccomendation}

RtDP is one of the innovations that can make it easier for Data Subject to transfer Personal Data from one Electronic System to another so that it does not take long for Data Subject to fill in the data needed during the sign up process on a P2P Lending application. However this can be a loophole for Personal Data to be accessed and misused by irresponsible parties. The implementation and implementation of RtDP must be in line with the Protection of Personal Data as stated in POJK No. 77, SPBE's Presidential Regulation, SDI's Presidential Regulation, PSTE Government Regulation and Draft PDP AFTECH.

P2P Lending Operators who implement RtDP in their management, both for registration and for other purposes for the benefit of Data Subject must have adequate technical capacity to do so and can guarantee the security of the process of portability of personal data, in short said the Electronic System it owns must be reliable, secure and responsible.

\section{REFERENCES}

\section{Books}

Lachlan Urquhart, Neelima Sailaja dan Derek McAuley. (2017). "Realising the Right to Data Portability for the Domestic Internet Of Things", England: Springer.

Rhenald Kasali. (2017). "Disruption”, cet. 6. Jakarta: PT Gramedia Pustaka Utama

Soerjono Soekanto, Sri Mamudji. (2004). "Penelitian Hukum Normatif, cet ke-8". Jakarta: PT Raja Grafindo Persada.

Saefullah Wiradipradja. (2016). "Penuntun Praktis Metode Penelitian dan Penelitian Karya Ilmiah, cet. 2". Bandung: CV Keni Media.
Subekti. (1979). "Pokok-Pokok Hukum Perdata". Jakarta: Intermasa.

Wirjono Prodjodikoro. (1993). "Azas-azas Hukum Perjanjian". Bandung: Sumur Press.

\section{Journals}

Ahmad, D., \& Thalib, M. C. (2019). Tanggung Jawab Hukum Pelaku Usaha Terhadap Peredaran Kosmetik Yang Tidak Memiliki Izin Edar. JURNAL LEGALITAS, 12(2), 100109.

Wijaya, A. (2019). Mekanisme Koordinasi dan Singkronisasi Lembaga Kementerian Negara Suatu Praksis Menuju Kabinet Yang Efektif. Al-Ahkam, 15(2), 69-80.

Andra Giurgiu \& Gérard Lommel. (2014). "A New Approach to EU Data Protection : More Control over Personal Data and Increased Responsibility". Critical Quarterly for Legislation and Law Vol. 97 No. 1: 17.

Ahmad, A., \& Nggilu, N. M. (2020). Denyut Nadi Amandemen Kelima UUD 1945 melalui Pelibatan Mahkamah Konstitusi sebagai Prinsip the Guardian of the Constitution. Jurnal Konstitusi, 16(4), 785-808.

Alhasni, M. R., Badu, L. W., \& Nggilu, N. M. (2019). Menakar Peran Kepolisian Dalam Mencegah Tindak Pidana Pencabulan Terhadap Anak di Bawah Umur.JURNAL LEGALITAS, 12(2), 110-123.

Amer, N. (2020). Analisis Pembubaran Organisasi Kemasyarakatan Dalam Perspektif Negara Hukum. JURNAL LEGALITAS, 13(01), 1-15.

Fitriani, N. (2019). Tinjauan Yuridis Kekuatan Pembuktian Keterangan Saksi Anak Dalam Persidangan Perkara Pidana. JURNAL LEGALITAS, 12(1), 14-24.

Harun, R. S., Dungga, W. A., \& Tome, A. H. (2019). Implementasi Asas Itikad Baik Dalam Perjanjian Transaksi Jual Beli Online. JURNAL LEGALITAS, 12(2), 90-99.

Lakoro, A., Badu, L., \& Achir, N. (2020). Lemahnya Kepolisian Dalam Penanganan Tindak Pidana Perjudian Togel Online. JURNAL LEGALITAS, 13(01), 3150.

Michele Loi dan Paul Olivier Dehaye. (2017). "If Data Is The New Oil, When Is The 
Extraction of Value From Data Unjust". Philosophy and Public Issues - Tyranny, Democracy, and Economy Vol. 7 No. 2: 139

Noriko Higashizawa dan Yuri Aihara. (2017).

"Data Privacy Protection of Personal Information Versus Usage of Big Data: Introduction of the Recent Amendment to the Act on the Protection of Personal Information (Japan)". Defense Counsil Journal Vol. 84 No. 4: 1.

Paul De Hert, Vagelis Papakonstantinou, Gianclaudio Malgieri, Laurent Beslay, Ignacio Sanchez. "The Right To Data Portability In The GDPR: Towards UserCentric Interoperability of Digital Services". Computer Law and Security Review, Vol. 34 No. 2: 195

Sinta Dewi Rosadi. (2018). "Perlindungan Privasi Dan Data Pribadi Dalam Era Ekonomi Digital Di Indonesia". Jurnal Veritas et Justicia Vol. 4 No. 1: 88

\section{Online References}

Data of Registered and Licensed P2P Lending Operators at OJK

Dennis D. Hirsch. (ed. June, 2014). "The Glass House Effect: Big Data, The New Oil, and the Power of Analogy". Maine Law Review Vol. 66 No. 2: 374.

David Parkins. "The World's Most Valuable Resource Is No Longer Oil, But Data", Retrieved from https://www.economist.com/leaders/. Accessed August 12, 2020.

Janis Wong \& Tristan Henderson. (October 2018). "How Portable is Portable? Exercising the GDPR's Right to Data Portability", Association for Computing Machinery.

\section{Laws}

Financial Services Authority Regulation No. 77 of 2016 concerning Information Technology-Based Money Borrowing Services

Government Regulation No. 71 of 2019 concerning The Implementation of Electronic System and Transactions

Presidential Regulation No. 39 of 2019 concerning One Indonesian Data

Regulation of the Financial Services Authority No. 77 of 2016 concerning Information Technology-Based Money Borrowing Services.

Regulation of the Minister of Communication and Informatics

The PDP Bill

the AFTECH PDP Standard Draft

Number 20 of 2016 concerning the Protection of Personal Data in Electronic Systems. 